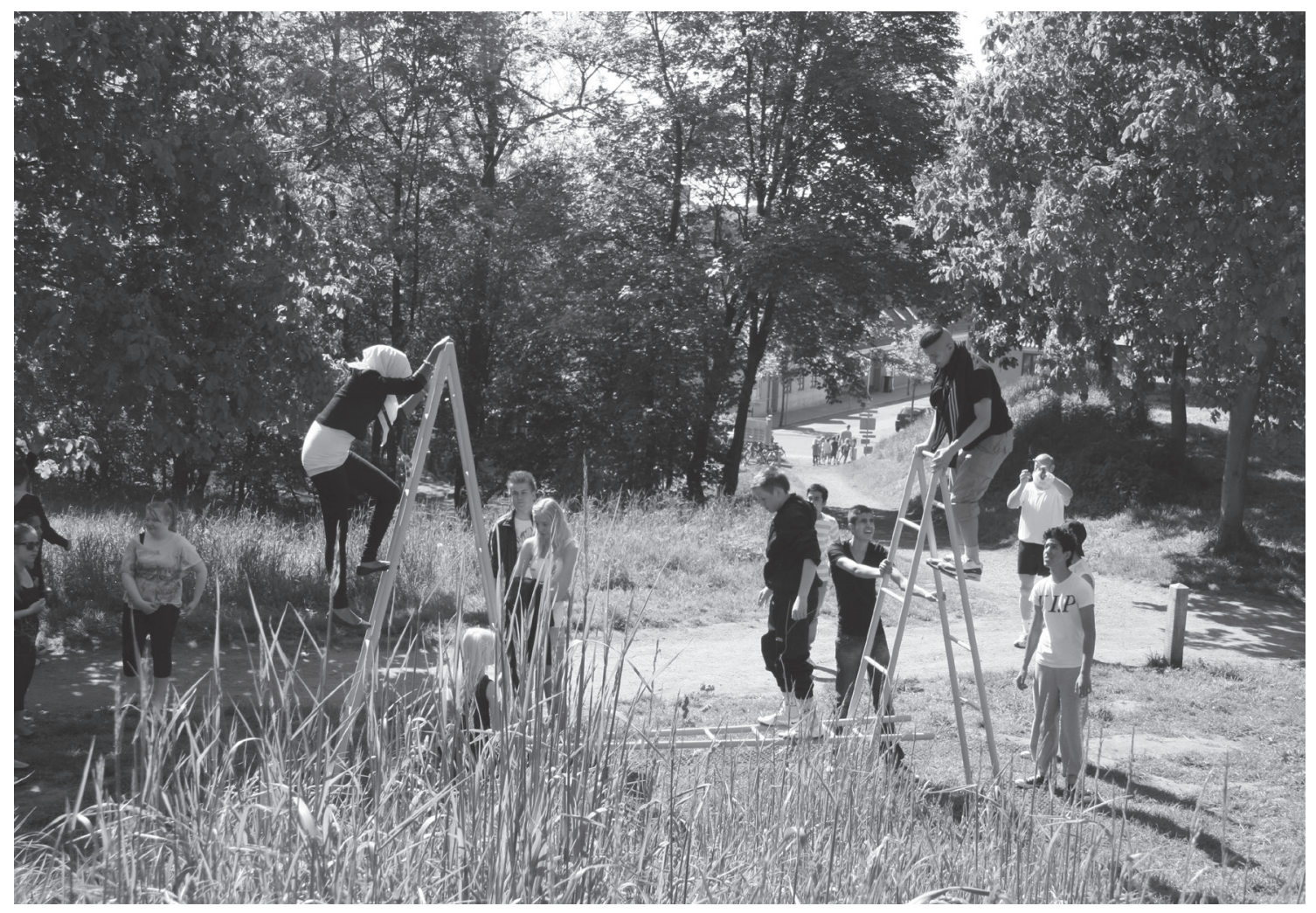

\title{
En god (om)vej til mere rekreativ fysisk aktivitet i hverdagen
}


Der er blandt folkesundhedseksperter en gryende konsensus om, at fysisk inaktivitet næstefter rygning kan regnes som den største trussel mod folkesundheden i den vestlige verden (Bauman, 2004; Blair, 2009). Rygning, indtag af alkohol og usunde madvarer kan reguleres med afgifter eller deciderede forbud, men i forhold til fysisk inaktivitet er disse greb ikke i samme grad politisk eller etisk mulige. Oplysningskampagner om vigtigheden af fysisk aktivitet har derfor typisk været det middel, som man har tyet til. Og for at stadfæste fysisk aktivitet som en overkommelig størrelse har WHO og statslige organer da også kommet med anbefalinger om minimumskriterier, fx 10.000 skridt eller mindst 30 minutters moderat fysisk aktivitet for voksne (WHO, 2010). Det er dog fåtallet, der følger anbefalingerne, og utilsigtet kan sådanne oplysningskampagner bidrage til en yderligere skævvridning i sundheden, da det som oftest er de mest ressourcestærke befolkningsgrupper, der vil være lydhøre for sundhedsbudskaber (Cavill \& Bauman, 2004).

En fysisk strukturel forebyggelse kan i den henseende være en farbar vej i bestræbelserne på at mindske fysisk inaktivitet og samtidig udligne uligheden i sundheden (Troelsen, 2013). Forebyggelseskommissionen har i sit udredningsarbejde sat fokus på vigtigheden af at forebygge fysisk inaktivitet, hvor den fysiske planlægning tildeles en central rolle. I afrapporteringen fremkommer det blandt andet, at "Fysisk planlagning kan bidrage til at fremme fysisk aktivitet bredt hos hele befolkningen og dermed befolkningens sundhed [...]. Fx kan etableringen af fysiske rammer $i$ de bolignoere områder, der sikrer tilgangelighed og appellerer til fysisk aktivitet, og en infrastruktur, der fremmer aktiv fysisk transport, vare en potentiel kilde til livsstilsaendring for hele befolkningen, også de mindre ressourcestoerke samfundsgrupper" (Forebyggelseskommissionen, 2009).

Ansporet af Forebyggelseskommisionen, Verdenssundhedsorganisationens anbefalinger og ikke mindst Strukturreformen i 2007 er der i Danmark kommet en større bevågenhed på borgernes fysiske rammer. Overdragelsen af hovedansvaret for det sundhedsfremmende og forebyggende arbejde har medført en større kommunal fokusering på at indrette de fysiske rammer, så de i højere grad fremmer og integrerer fysisk aktivitet i hverdagen. (Indenrigs- \& Sundhedsministeriet, 2008).

Viden og forskning om, hvordan vi optimalt set indretter de fysiske rammer, så de bedst understøtter en fysisk aktiv livsstil, er i en kraftig udvikling. Internationalt og nationalt er der igangsat en række forskningsprojekter, som skal give os mere sikker viden om, hvordan den fysiske planlægning kan optimeres for at øge det fysiske aktivitetsniveau. Et konkret eksempel er udviklingsprojektet "En God Omvej" (EGO), som blev initieret og økonomisk støttet af Realdania og Lokale- og Anlægsfonden. I samarbejde med ni kommuner blev der etableret en række fysiske anlæg, der skulle give anledning til at slå vejen forbi og være mere fysisk aktiv i hverdagen.

Vi vil i artiklen beskrive og diskutere EGOprojektet som et eksempel på at fremme danskernes fysiske aktivitetsniveau. Formålet er på baggrund af resultaterne at skabe en opmærksomhed på en række faktorer, der bør medtænkes i planlægningen og indretningen af lokalområder, der skal appellere til mere rekreativ fysisk aktivitet i hverdagen.

UDVIKLINGSPROJEKTET "EN GOD OMVEJ" (EGO)

EGO-projektet har det erklærede formål, at "scette fokus på, hvordan den fysiske ramme kan 
skabe bedre vilkår for det aktive og sunde hverdagsliv med fokus på bevagelse $i$ det fri, lige der hvor man bor eller faerdes $i$ det daglige" (www. engodomvej.dk). Realdania og Lokale- og Anlægsfonden initierede projektet i januar 2010 ved at invitere landets kommuner til at indsende visionsoplæg. 59 kommuner bød ind med 78 visionsoplæg, hvor der blev udvalgt 15 oplæg, som hver fik $100.000 \mathrm{kr}$. til videre projektudvikling. Ud af de 15 forslag udvalgte et nedsat bedømmelsesudvalg december 2010 ni projekter, som fik støtte til realisering med op til $75 \%$ af anlægssummen, dog maksimalt to mio. $\mathrm{kr}$. til hvert projekt. Den resterende del skulle kommunen selv finansiere. Den samlede støtte fra fondenes side til realisering beløb sig til godt 14 mio. kr. plus en ramme på knap to mio. kr. til dækning af fondsafgifter. Med kommunernes medfinansiering blev der bygget for $i$ alt 19,5 mio. kr. Det billigste anlæg kostede 721.000 kr., mens det dyreste beløb sig til $3.210 .000 \mathrm{kr}$.

I efteråret 2012 stod i alt ni aktivitetsområder klar til brug. Der er etableret ni meget forskellige aktivitetsområder med stor variation i forhold til indhold og placering. Dog var områderne $\mathrm{i}$ en vis grad repræsentative for typiske områder, som er at finde i næsten alle danske byer. Således skete der anlægsarbejde i en park, på en parkeringsplads, i et idrætsanlæg, på græsplæner, på en station, i en ny bydel, på bytomter, langs en støjvold og i et kulturhistorisk område.

\section{Anlaegsprojekterne i EGO-projektet}

1. Byens Arena, Gladsaxe Kommune

2. Dronningens Bastion, Fredericia Kommune

3. En Voldsom Omvej, Solrød Kommune

4. Et bevægelseseksperimentarium i Sundhedscentrets park, Odsherreds Kommune
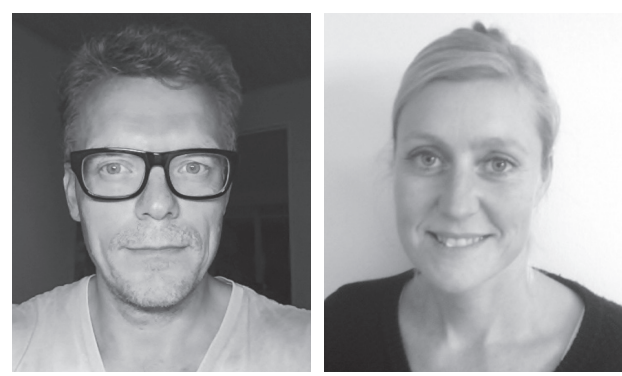

AF

JENS TROELSEN

\& CHARLOTTE

PAWLOWSKI

5. Naturparken, Mellem bakkedrag og dalstrøg, Sønderborg Kommune

6. Opfordring til udfordring. Kolding Kommune

7. PixlPark (Den digitale legeplads), Roskilde Kommune

8. Sidesporet, Middelfart Kommune

9. PulsPark i Ringkøbing, Ringkøbing-Skjern Kommune (ikke vist)

\section{VIDEN OM GODE OMVEJE}

I initieringen af EGO-projektet var der fra fondenes side en samtidig interesse $i$ at få mere indgående viden om brugen af anlæggene. Der blev derfor indgået et samarbejde med Institut for Idræt og Biomekanik, Syddansk Universitet (IOB-SDU), inden der var truffet beslutning om, hvilke anlæg som fik økonomisk støtte til anlægsarbejdet. Det muliggjorde forberedelsen af et studiedesign, hvor der kunne laves før- og eftermålinger i forhold til brugen af lokalområdet og de forandringer, som etableringen af anlæggene eventuelt måtte medføre. Det overordnede formål med studiedesignet var på den baggrund at bidrage med viden, som fremadrettet kan kvalificere lignende aktivitetsfremmende anlæg. Der er således til hvert anlæg, på nær PulsParken ${ }^{1}$ i Ringkøbing, lavet detaljerede analyser beskrevet i otte særskilte rapporter (Pawlowski et al., 2012a, 2012b, 


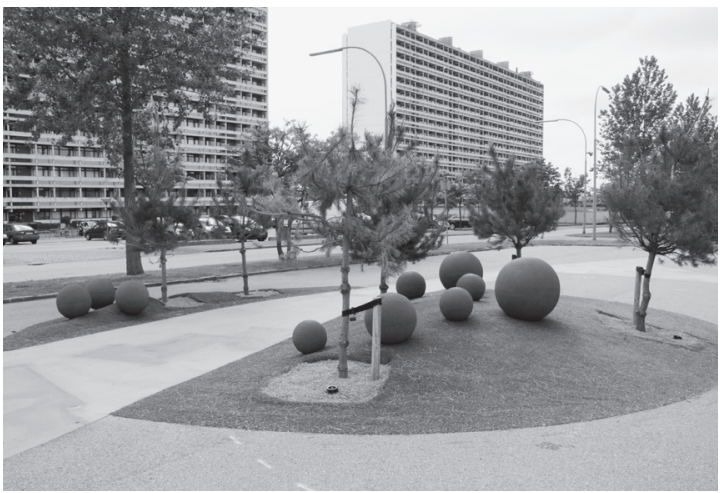

Byens Arena, Gladsaxe Kommune.

(Foto: Charlotte Skau Pawlowski)

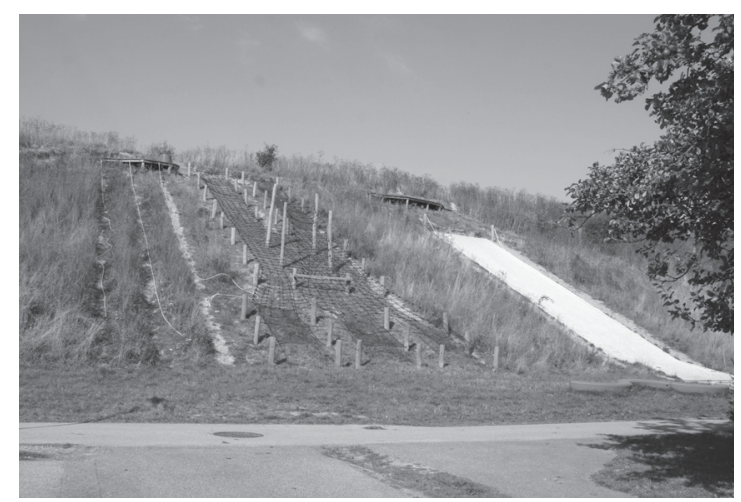

En Voldsom Omvej, Solrød Kommune.

(Foto: Charlotte Skau Pawlowski) 2012c, 2012d, 2012e, 2012f, 2012g). Samtidig er der lavet en procesanalyse, hvor tre udvalgte projekter blev fulgt i planlægnings- og anlægsfasen. Formålet med procesanalysen var at analysere forskellige interne og eksterne samarbejdskonstellationer med henblik på at afdække kvaliteter og barrierer i kommunernes arbejde med udviklingsprojektet (Pawlowski \& Troelsen, 2012).

Det følgende vil være afgrænset til at være præsentation af de generelle resultater opsamlet på tværs af de otte lokale analyser. Der lægges for med en præsentation af det anvendte studiedesign, metoder og bortfald, hvorefter resultaterne af de kvantitative og kvalitative analyser fremlægges, der tilsammen danner grundlag for en afsluttende diskussion og perspektivering af de gjorte fund i EGO-projektet.

\section{Studiedesign}

Undersøgelsens empiriske materiale består af en baselineundersøgelse og en follow-up undersøgelse, hvor der i begge tilfælde er anvendt både kvantitative og kvalitative metoder. Denne metodetriangulering er valgt for dels at opveje de fordele og ulemper, som hver af metoderne er forbundet med, og dels give en mere nuanceret

Tabel 1. Dataindsamlingsmetode og tidspunkt for dataindsamling

\begin{tabular}{|l|l|l|}
\hline Metode & Baseline & Follow-up \\
\hline $\begin{array}{l}\text { Feltobservation } \\
\text { Spørgeskemaundersøgelse }\end{array}$ & Februar 2011 & Maj-september 2012 \\
\hline
\end{tabular}

* Pga. senere anlægning af projekter i Fredericia, Kolding, Middelfart, Solrød og Sønderborg blev follow-up undersøgelsen her udsat til august-september 2012. 


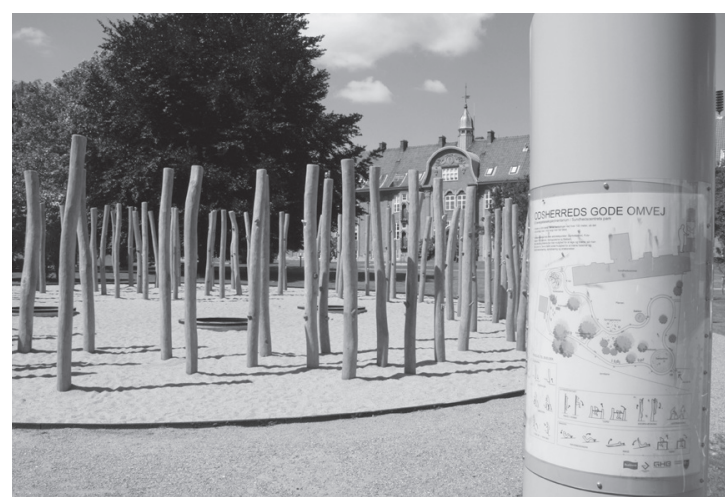

Et bevægelseseksperimentarium i Sundhedscentrets park, Odsherreds Kommune. (Foto: Charlotte Skau Pawlowski)

belysning af det undersøgte (Neuman, 2011). Tabel 1 viser anvendte metoder for dataindsamling og tidspunkt for gennemførelse.

Der blev i hvert lokalområde foretaget én feltobservation før og én efter etableringen af anlægget. Formålet med observationerne var at undersøge ændringer over tid i brugen af området $\mathrm{i}$ forhold til brugernes alder, sociale grupperinger, aktivitetsformer, tidsforbrug og generelle adfærdsmønster. For at understøtte observationerne blev der også foretaget ustrukturerede interviews med tilfældigt udvalgte brugere, forbipasserende, naboer mv. med henblik på nærmere forståelse af områdets brug.

I forhold til spørgeskemaundersøgelserne blev der for at forbedre rekrutteringen af respondenter indgået et samarbejde mellem IOB-SDU og den enkelte kommune. Spørgeskemaet bestod af en række spørgsmål med henblik på at indhente selvrapporterede oplysninger om brug af lokalområdet samt subjektive vurderinger af lokalområdets karakter og facilitetsdækning. Spørgsmålene og svarkategorierne var helt ens-

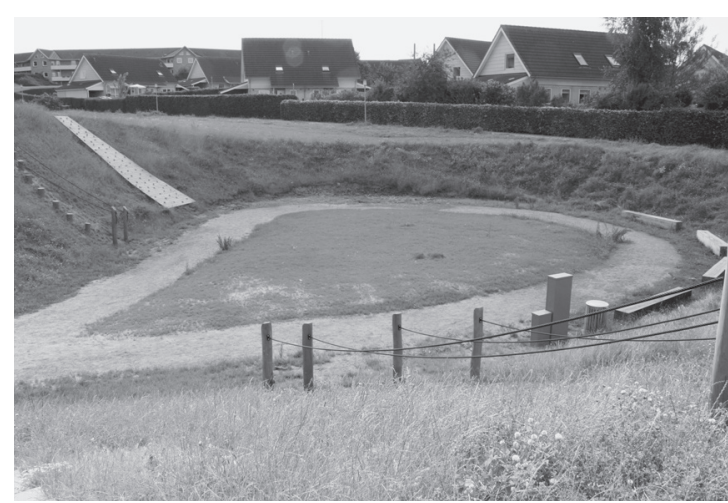

Naturparken, Mellem bakkedrag og dalstrøg, Sønderborg Kommune. (Foto: Charlotte Skau Pawlowski)

lydende i baseline- og follow-up undersøgelsen. Follow-up spørgeskemaet havde dog en række supplerende spørgsmål omhandlende brug af og tilfredshed med det færdiggjorte EGO anlæg.

I rekrutteringen af respondenter blev der lavet tilfældige udtræk blandt borgere fra 16 år i det lokalområde, hvor anlægget blev placeret. Lokalområdets udstrækning blev defineret med en netværksbuffer på ca. $1,5 \mathrm{~km}$. omkring anlægget svarende til ca. 5 minutters cykling eller 15-20 minutters gang. Efterfølgende blev adressedubletter fjernet, således at der kun blev valgt en respondent pr. husstand, undtaget i Sønderborg og Middelfart Kommune med lokale ønsker om bedre dækningsgrad. Herefter sendte kommunen et informationsbrev til samtlige respondenter bl.a. med oplysningen om, at man enten kunne besvare spørgeskemaet elektronisk eller rekvirere et papirspørgeskema og returnere det udfyldte i en svarkuvert. Kommunen sendte som opfølgning to rykkerbreve med ca. 14 dages mellemrum til respondenter, der endnu ikke havde svaret på spørgeskemaet. 
I tabel 2 vises antal udtrukne respondenter, antal besvarede spørgeskemaer samt svarprocenter for baseline- og follow-up undersøgelserne.

I alle områder er respondenterne fra 16 år og op. I Middelfart og Roskilde er respondenterne dog begrænset til aldersgruppen 16-24-årige bosat i det afgrænsede lokalområde. I forlængelse heraf skal det bemærkes, at antallet af respondenter i Middelfart og Roskilde er væsentlig mindre end i de øvrige seks områder, hvilket kan influere på resultaterne af de områdeopdelte analyser.

Som gældende for de kvalitative analyser er formålet med de kvantitative analyser at undersøge ændringer over tid. Derfor vil formidlingen af de følgende resultater udelukkende bygge på svarene givet af de 1.775 responden- ter, der har besvaret både baseline - og followup spørgeskemaet.

\section{Resultater af den kvantitative analyse \\ Tilfredshed $i$ lokalområderne}

Borgerne i de afgrænsede lokalområder gav i spørgeskemaerne generelt udtryk for en meget stor tilfredshed med anlæggene, idet $70 \%$ angiver, at de er glade for, at EGO anlæggende er etableret. Samtidig anfører flere respondenter, at forholdene er forbedret for at mødes (fra 57 $\%$ i baseline til $67 \%$ i follow-up), for at lege (fra $60 \%$ i baseline til $70 \%$ i follow-up) og for at være fysisk aktiv (fra $58 \%$ i baseline til 68 $\%$ i follow-up). Diagram 1 viser specifikt udviklingen i lokalområderne $\mathrm{i}$ forhold til respondenternes oplevelse af mulighederne for at være fysisk aktiv.

Tabel 2. Respondenter og svarprocent.

\begin{tabular}{|c|c|c|c|c|c|c|c|}
\hline & \multicolumn{2}{|c|}{$\begin{array}{l}\text { Udtrukne } \\
\text { respondenter }\end{array}$} & \multicolumn{3}{|c|}{$\begin{array}{c}\text { Antal besvarende besvarede } \\
\text { spørgeskemaer }\end{array}$} & \multicolumn{2}{|c|}{ Svarprocent (\%) } \\
\hline Kommuner & Baseline & Follow-up & Baseline & Follow-up & Begge* & Baseline & Follow-up \\
\hline Fredericia & 1.179 & 1.117 & 460 & 379 & 262 & 39 & 34 \\
\hline Gladsaxe & 1.973 & 1.912 & 705 & 554 & 366 & 36 & 29 \\
\hline Kolding & 1.148 & 1.039 & 476 & 273 & 221 & 42 & 26 \\
\hline Middelfart & 264 & 246 & 128 & 37 & 30 & 49 & 15 \\
\hline Odsherred & 1.147 & 1.127 & 576 & 374 & 340 & 50 & 33 \\
\hline Roskilde & 793 & 738 & 121 & 143 & 48 & 15 & 19 \\
\hline Solrød & 1.158 & 1.095 & 596 & 383 & 316 & 52 & 35 \\
\hline Sønderborg & 1.042 & 951 & 457 & 232 & 192 & 44 & 24 \\
\hline I alt & 8.704 & $8.225^{\star \star}$ & 3.489 & 2.375 & 1.775 & 40 & 29 \\
\hline
\end{tabular}

^Betegnelse "Begge" dækker over de respondenter, der både har besvaret baseline- og follow-up spørgeskemaet.

$\star \star$ Der var et frafald på i alt 479 personer grundet bl.a. fraflytning, dødsfald, samt ønske om ikke at deltage i undersøgelsen. 


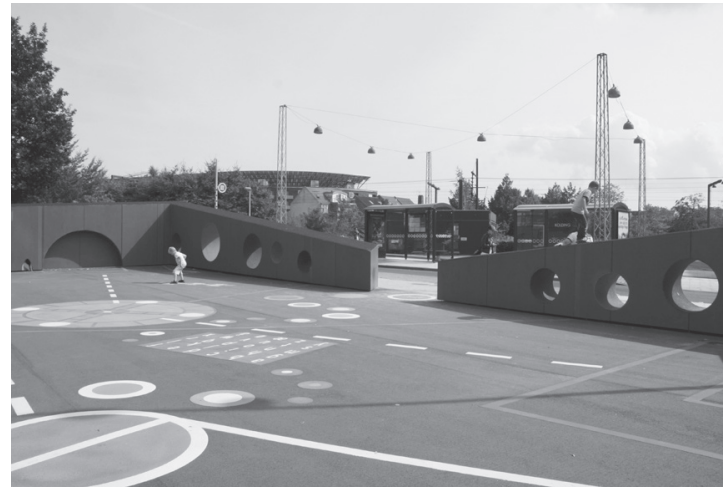

Opfordring til udfordring. Kolding Kommune.

(Foto: Charlotte Skau Pawlowski)

Knap halvdelen (46 \%) af de adspurgte respondenter anførte, at lokalområderne med de nye anlæg generelt var blevet et bedre sted at bo. Der var med andre ord en udbredt tilfreds-

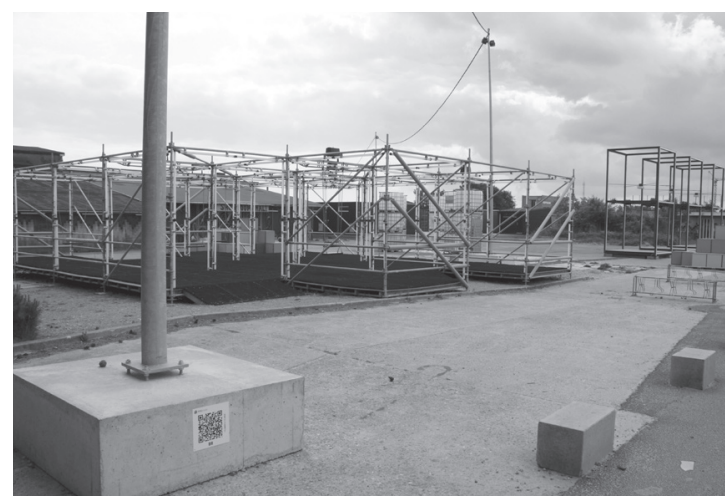

PixlPark (Den digitale legeplads), Roskilde Kommune. (Foto: Charlotte Skau Pawlowski)

hed i lokalområderne, hvor EGO anlæggene var placeret. Det interessante er imidlertid om respondenternes positive omtale af projektet og deres oplevelse af, at der er gode muligheder

Diagram 1. Respondenter, der anfører, at mulighederne for fysisk aktivitet i lokalområdet er meget gode til gode ved baseline og follow-up fordelt på område, angivet i procent.

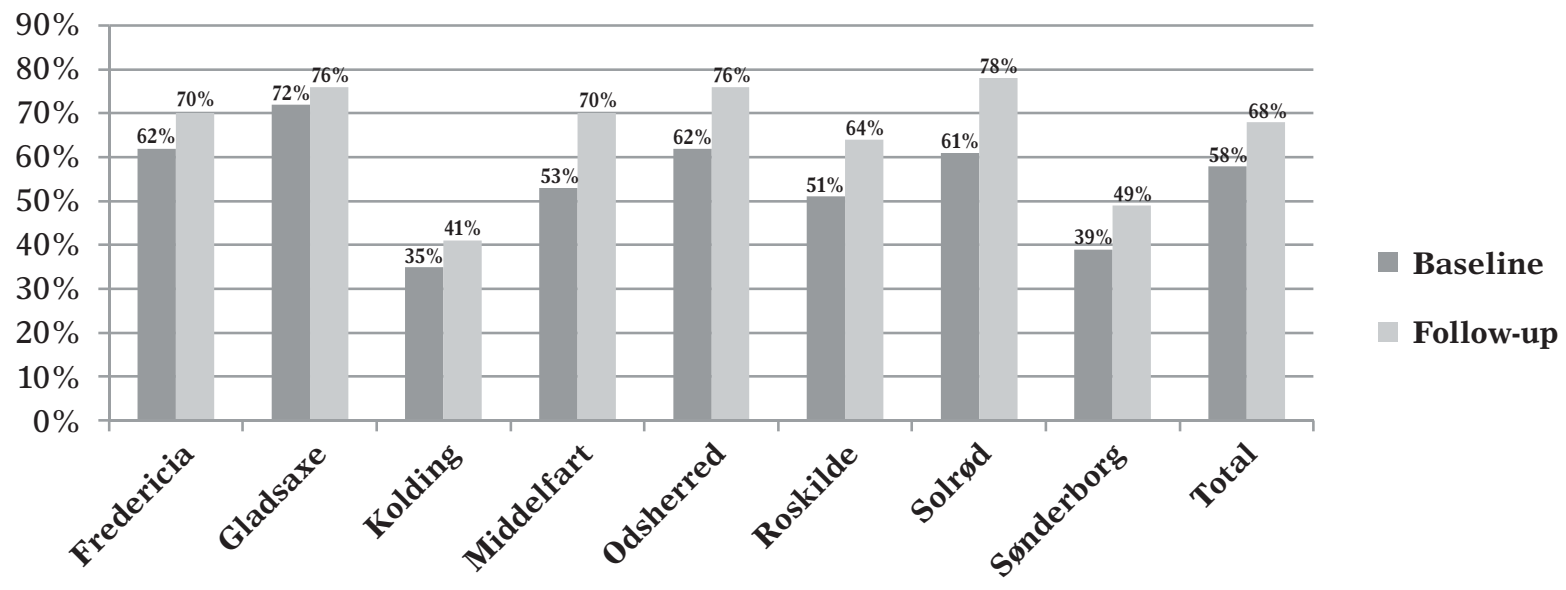

\section{Follow-up}


for at bevæge sig i området, også omsættes til brug og mere fysisk aktivitet i lokalområderne

\section{Svingende brug}

De kvantitative analyser af spørgeskemadataene viste stor forskel på, hvor hyppigt de enkelte anlæg blev brugt, men gennemsnitligt brugte $18 \%$ af respondenterne ( $\geq 16$ år) anlæggene 1-3 gange pr. måned. 3 \% var hyppigere brugere og anvendte anlæggene 1-7 gange pr. uge, mens de resterende $79 \%$ anførte, at de sjældent eller aldrig brugte anlæggene. De hyppigste brugere er de 25-44 årige og de mindst hyppige brugere er de 16-24 årige samt de 65+ årige.

Der kunne ikke spores signifikante ændringer i beboernes rekreative aktivitetsmønstre foranlediget af anlæggene, og der kunne heller ikke registreres, at EGO anlæggene bidrog til, at det generelle fysiske aktivitetsniveau øgedes i lokalområderne. Ca. to tredjedele af respondenterne anførte, at de spadserer, cykler eller har anden lettere motion mindst 4 gange om ugen (hhv. 63 \% i baseline og $64 \%$ i follow- up). Hver femte dyrker moderat fysisk aktivitet $\mathrm{i}$ form af motionsidræt eller udfører tungt havearbejde eller lignende mindst fire timer om ugen (hhv. $19 \%$ i baselineundersøgelsen og $20 \%$ i follow-up undersøgelsen) og $4 \%$ angav i både baseline- og follow-up undersøgelsen, at de træner hårdt og dyrker konkurrenceidræt regelmæssigt og flere gange om ugen. Blandt de $21 \%$ af beboerne, der i spørgeskemaet svarede, at de brugte EGO anlæggene i deres lokalområde, angav knap halvdelen (43\%) imidlertid, at faciliteterne på anlæggene i høj grad (5\%) til nogen (38\%) havde givet dem mere bevægelse i hverdagen svarende til, at ca. hver 10 . beboer i lokalområderne gav udtryk for, at anlægget havde givet dem mere bevægelse i hverdagen.

Hvad denne bevægelse dækker over og hvem det er, der bevæger sig på anlæggene, blev belyst gennem den komplementerende kvalitative del af undersøgelsen, hvor der gennemførtes feltobservationer og interviews med brugere og folk på og i umiddelbar nærhed af anlæggene (Pawlowski et al., 2013).

Diagram 2. Brug af EGO aktivitetsområderne fordelt på alder, angivet i procent.

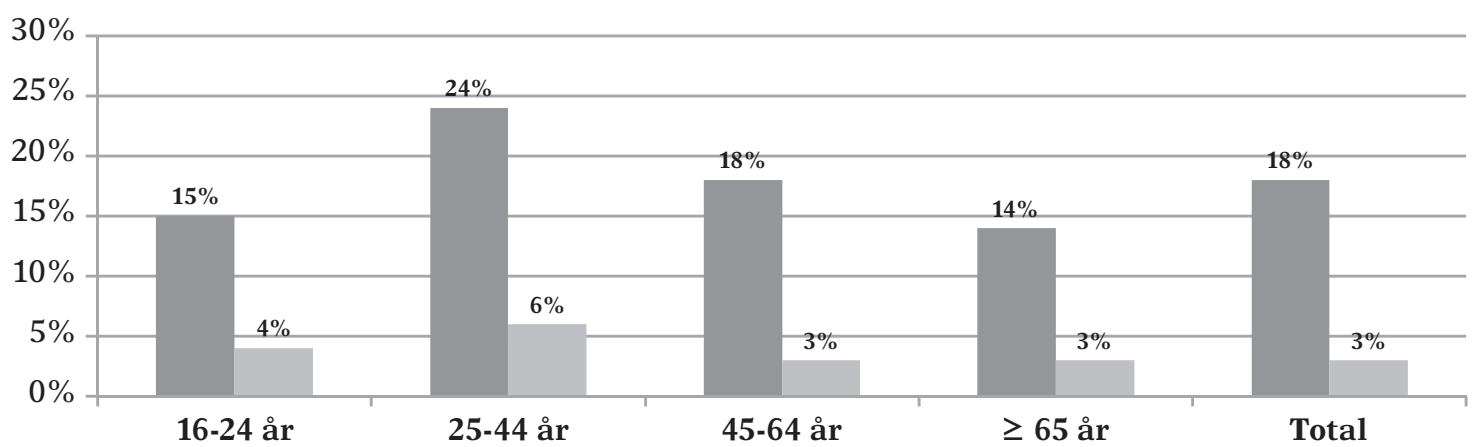

1-3 gange om måneden

1-7 gange om ugen 


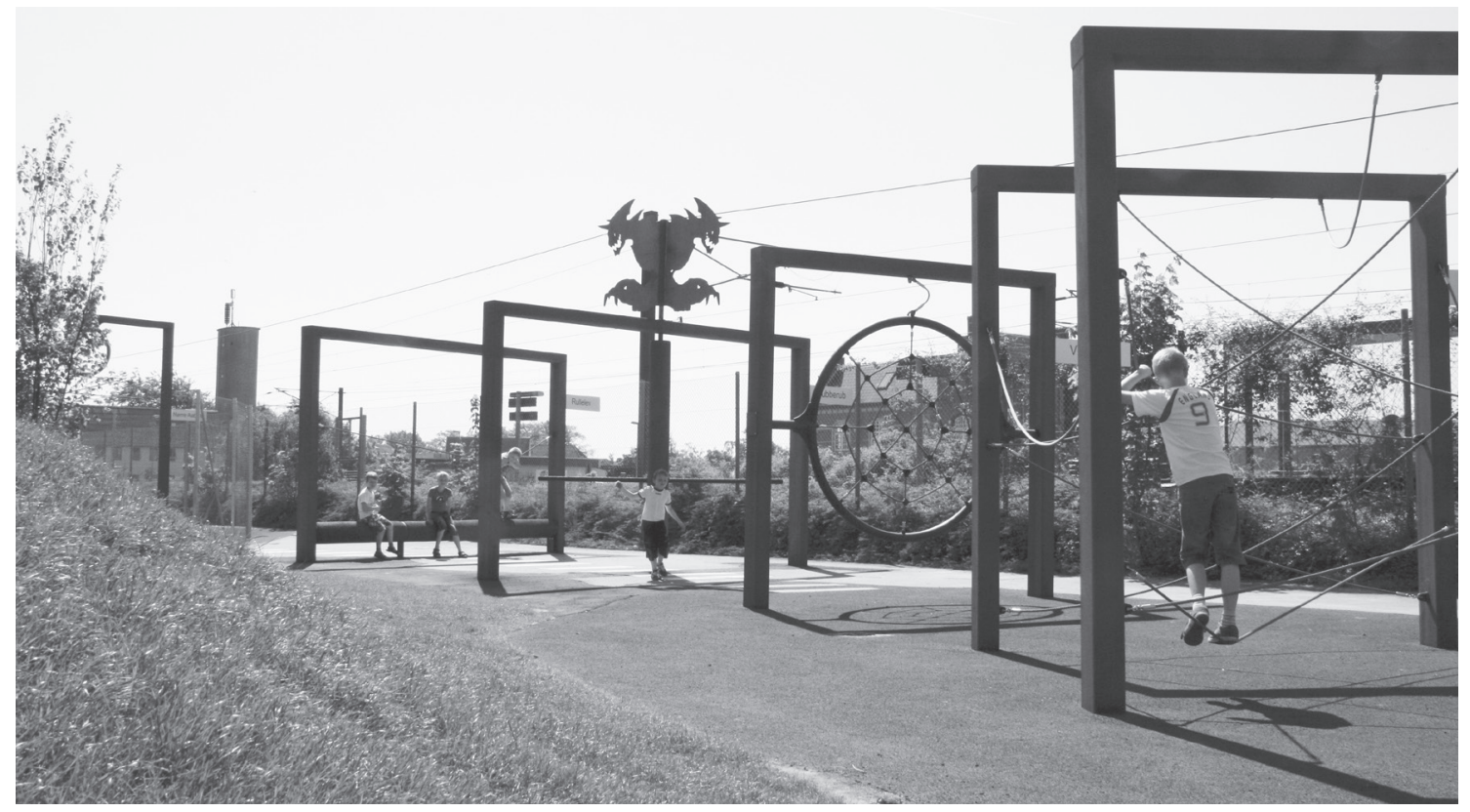

Sidesporet, Middelfart Kommune. (Foto: Charlotte Skau Pawlowski)

\section{Resultater af den kvalitative analyse}

Hvem brugerne er og hvordan de bruger anlaeggene? De kvalitative studier viste, at der var mange forskellige brugergrupper knyttet til anlæggene.

Om eftermiddagen løb der af og til børn ind på multibanen, hoppede på nogle af asfaltens afmorkninger, kravlede gennem vaeggens huller eller gik på line på vaggen, imens de sammen med deres forceldre passerede multibanen på vej ind mod gågaden [...] Banen var også en del brugt om eftermiddagen, specielt af unge, der mødtes på pladsen og spillede fodbold og basketball (uddrag af feltnoter).
Både børn, unge, voksne, ældre, daginstitutioner, skoler og foreninger brugte anlæggene. Børn, specielt dem i den tidlige skolealder, var den brugergruppe, der kom mest på anlæggene. Børnene kom typisk med dagsinstitution eller skole i løbet af formiddagen, og i løbet af eftermiddagen og i weekender enten alene eller med venner, søskende, forældre, bedsteforældre eller sågar oldeforældre. De unge i lokalområderne brugte anlæggene overvejende i eftermiddagstimerne eller om aftenen, hvor også voksne og ældre benyttede anlæggene. De primære brugere boede i lokalområdet, men to af anlæggene formåede også at tiltrække brugere fra mere fjerntliggende områder. 


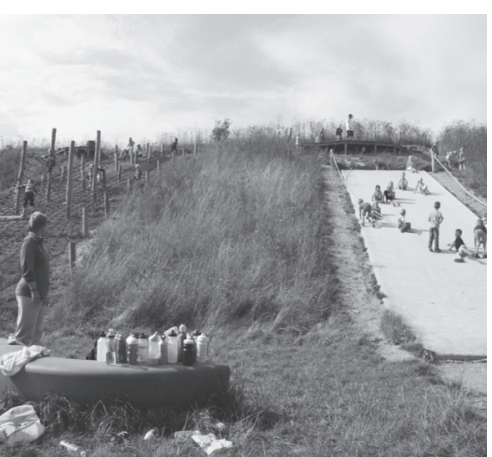

En voksen ser på, mens børn fra en næerliggende SFO leger på Solrøds "En Voldsom Omvej".

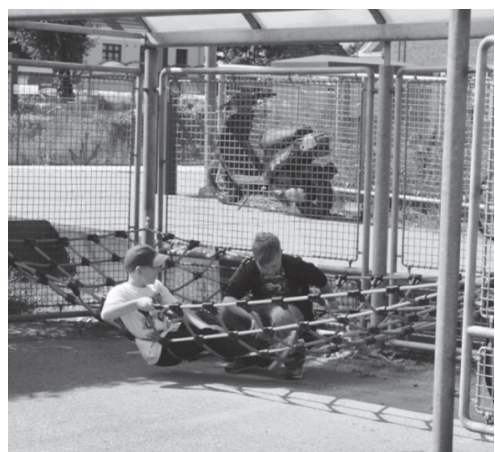

To unge drenge hænger ud i et net på Sidesporet, Nørre Aaby, Middelfart Kommune

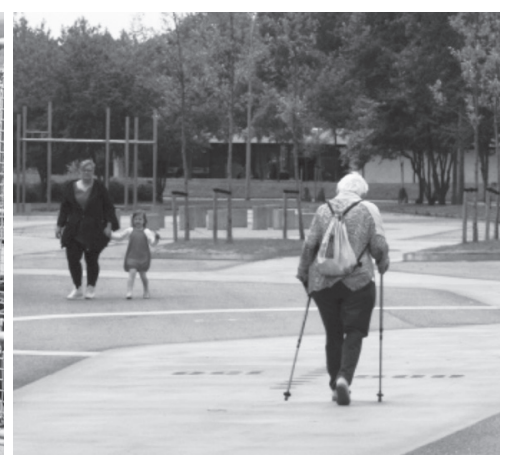

En æeldre dame går stavgang på den orangemalede sti i Byens Arena i Gladsaxe.

Foto: Charlotte Pawlowski

Overordnet kan der karakteriseres to brugergrupper. Den største brugergruppe var målbevist opsøgende for at lege, motionere eller tage ophold, mens den anden gruppe mere impulsivt stoppede op og brugte stederne på deres vej forbi anlægget. Det var særligt børnene, der var fysisk aktive på anlæggene med lege initieret af børnene selv, fx rolleleg, gemmeleg og fangeleg. Børnene brugte både anlæggenes faciliteter og området omkring faciliteterne til deres leg. Faciliteterne indgik i aktiviteterne, som de funktionelt var tiltænkt, men også på alternative og uventede måder. Modsat børnene brugte de unge faciliteterne mere passivt enten siddende eller liggende, hvor anlæggene primært tjente formålet som et være- og hæng-ud-sted med vennerne. De voksne og ældre brugere kan kategoriseres i to type brugere. Størstedelen af de voksne og ældre brugte anlæggene sammen med deres børn, børnebørn og oldebørn, hvor de overvejende var stillestående eller stillesiddende og kun aktive ved faciliteterne i de til- fælde, hvor børnene havde brug for en hjælpende hånd. Den anden type voksne og ældre kom uden børn og brugte anlæggene til decideret træning såsom stavgang, løb og styrketræning, hvor elementer som afmærkede stier, skråninger eller fitnessudstyr blev benyttet som elementerne oprindeligt var tiltænkt.

\section{Oplevede faktorer med betydning for brug}

Beboerne i lokalområdet gav udtryk for en række væsentlige faktorer med betydning for brugen af anlæggene. Her spiller tilgængelighed og vedligeholdelse en fremtrædende rolle.

En loerer forklarede, at hun flere gange havde oplevet, at en haengebro, der fører til anloegget havde voeret lukket for passage: "Det er trist for det betyder, at folk ikke gider, at komme igen" [...] Der kom en del $i$ løbet af dagen for at tage en genvej henover hoengebroen. Mange af dem blev irriterede over, at de ikke kunne passere broen.

En ung mand udbrød til to medfølgende 
veninder: "Det er møg irriterende, at vi ikke kan komme over broen" (uddrag af feltnoter).

Tilgængelighed var medbestemmende for brugen af anlæggene, hvilket især havde betydning for de brugergrupper, der spontant brugte anlæggene. De anlæg, der i særlig høj grad blev brugt spontant, var således beliggende ved befærdede pladser, veje eller stisystemer og havde gode adkomstforhold modsat anlægget i ovenstående eksempel, hvor en af de primære veje til anlægget var afspærret gentagende gange pga. ødelæggelser. Flere steder havde beboerne oplevet mislighold i form af hærværk, defekte faciliteter, ukrudt og affald. Misligholdte anlæg havde negativ indflydelse på brugen, idet beboerne gav udtryk for manglende lyst til at opsøge stedet igen.

En tredje central faktor med betydning for anlæggenes brug var brugernes evne og mulighed for at afkode faciliteternes brug.

Flere novnte, at de ikke vidste, hvad nogle

af faciliteterne skulle bruges til. En pige,

der legede på svaevebanen, spurgte sin

veninde: "Skal vi prøve det der?" og pegede

over på nogle traestubbe. Veninden svarede:

"Jamen, jeg ved ikke en gang, hvad man

skal bruge det til” (uddrag af feltnoter).

Simple faciliteter ligger i højere grad op til leg og fysisk aktivitet end nytænkende, innovative faciliteter, hvor funktionaliteten umiddelbart var vanskelig at afkode. Det syntes i særlig høj grad at være et irritationsmoment blandt de voksne brugere, men også flere børn undrede sig over nogle af faciliteternes funktion. Brugen af faciliteter, hvor medbragt udstyr, fx en bold eller en mobiltelefon, var en forudsætning for brugen, blev desuden i langt mindre grad brugt, da beboerne oplevede, at disse faciliteter krævede planlægning og ikke ansporede til spontan brug.

\section{GODE OMVEJE TIL BEVAEGLSE}

\section{OG FYSISK AKTIVITET}

På baggrund af resultaterne af analysearbejdet kan der stilles spørgsmålstegn ved, om EGO-projektet giver de optimale rammer for mere fysisk aktivitet i hverdagen. De fysiske, strukturelle betingelser er til stede. Anlæggene har generelt en placering og synlighed i lokalområderne som et potentielt sted, hvor man kan vælge at være fysisk aktiv. Hver 10 . respondent i undersøgelsen anfører da også, at anlægget konkret har medført mere bevægelse i deres hverdag, og parallelt kan der observeres en øget koncentration af aktive børn, som efter færdiggørelsen af anlæggene opsøger stederne for at lege og opholde sig. Anlæggene i lokalområderne har således tjent formålet at gøre lokalbeboerne opmærksom på, at leg og fysisk aktivitet er en mulighed, som de er velkommen til at benytte sig af. En opstået mulighed, som lokalbeboerne samtidig tilkendegiver meget stor tilfredshed med.

Det må dog også konstateres, at 79 \% af respondenterne sjældent eller aldrig bruger anlæggene. Taget bortfaldets størrelse i betragtning, kan det formodes, at antallet af daglige ikke-brugere er endnu større blandt voksne. På den baggrund kan det konstateres, at vejen til bevægelse og fysisk aktivitet kan opleves som en omvej. Rekreativ fysisk aktivitet er ikke en betingelse i dagligdagen. Det er et aktivt til- eller fravalg. Fysisk aktivitet er til en vis grad uomgængeligt i forhold til huslige forpligtigelser, arbejdsbetingede opgaver eller behov for mobilitet til hverdagens mange gøremål, og i de tilfælde kan de fysiske strukturelle rammer være regulerende for omfanget og intensiteten af de fysiske aktivitetsmønstre. Rekreativ fysisk aktivitet, som EGO-projektet ansporer til, er derimod tegn på overskud til at være noget 
for sig selv og andre, og her skal barriererne være lave og omvejene få, hvis der i den sparsomme, fortravlede fritid skal levnes plads til rekreation. Rekreativ fysisk aktivitet er også forbundet med en vis træghed, hvor fritidsvaner ikke uden videre lader sig ændre. Ændrede aktivitetsmønstre kræver overbevisning om en anderledes prioritering af gøremål og en ændret planlægning af dagligdagen. Det anvendte studiedesign har her en klar begrænsning, idet follow-up undersøgelserne blev gennemført relativ kort tid efter opførelsen af anlæggene. På den måde registreres kun korttidseffekten, der ikke tager højde for, at EGO-projektet på sigt kan have foranlediget et højere aktivitetsniveau i lokalområderne.

\section{VEJE TIL MERE UORGANISERET REKREATIV FYSISK AKTIVITET}

I højt teknologiserede samfund kan fysisk aktivitet i mange tilfælde vælges helt fra pga. bilen, elevatoren og alle de øvrige passiviserende hjælpemidler og gadgets, der findes i hjemmet, på arbejdspladsen og i de offentlige rum. Den teknologiske udvikling vil de færreste være foruden, og et decideret bevidst tilbageskridt med mindre økonomisk og teknologisk råderum vil være utænkelig, selvom det er vist at være til gavn for folkesundheden (Franco et al., 2007). Den stigende grad af fysisk inaktivitet, som især vinder frem i den vestlige verden, bærer dog også kimen til at udløse latente behov for at røre og bevæge sig, men det lukrerer i høj grad på god planlægning, funktionalitet og vedligeholdelse af de tilbudte rammer.

For at påvirke især ressourcesvage danskeres fysiske aktivitetsniveau i opadgående retning er der på baggrund af EGO-projektet en række forhold, som byplanlæggere, arkitekter mv. bør være opmærksom på (Pawlowski et al, 2013).
Fysisk aktiverende anlæg skal være let tilgængelige med en synlig placering og stort flow af forbipasserende for både at skabe synlighed af aktivitet og oplevelse af tryghed med flere brugere omkring sig. Samtidig skal der også være tilstrækkelig plads og en overskuelighed af anlægget for dels at skabe nødvendigt råderum og dels mulighed for en vis privathed med de igangværende aktiviteter. Det er også væsentligt for en vedholdende brug, at anlæggets faciliteter er simple at afkode, giver udfordringer, opleves varierende og har et udviklingspotentiale for nye aktiviteter kan opstå. Og endelig er vedligeholdelse nødvendig for at sikre anlæggets funktionalitet og æstetik. Ødelagte eller misligholdte anlæg, defekte faciliteter, overfyldte skraldespande mv. har ifølge brugerne i lokalområderne negativ indflydelse på brugen.

Det er væsentligt med god planlægning, funktionalitet og vedligeholdelse for fremme af rekreativ fysisk aktivitet, da aktivitetsniveauet ikke er bestemt af nødtvungne valg, men beror på bl.a. tid, lyst og motivation for at bevæge sig. Her er det væsentligt at vise, og konkret i lokalområdet at delagtiggøre for alle, at rekreativ fysisk aktivitet er et muligt alternativ til en mere passiv, inaktiv livsstil.

For mere indgående viden er det nødvendigt med studier, som nærmere belyser, hvilke incitamenter og barrierer, der er knyttet til rækken af til- og fravalg i hverdagen. Analyserne i EGO-projektet er baseret på spørgeskemadata og enkeltdagsobservationer, så et væsentligt supplement vil være mere udførlige studier, som nærmere undersøgte fx intra- og interpersonelle begrænsninger for valg af fritidsaktiviteter (Crawford et al., 1991) eller intenderede handlinger i forhold til fritidsadfærd (Ajzen \& Driver, 1992). Det vil også styrke vores viden, hvis der blev gennemført yderligere follow-up 
studier for på den måde at undersøge langtidseffekterne af anlæggene i forhold til varigheden, intensiteten og frekvensen af borgernes fysiske aktivitetsniveau.

EGO-projektet er et udviklingsprojekt, hvor en række meget forskellige anlæg er afprøvet i meget forskellige fysiske omgivelser. Det har givet et nuanceret erfaringsgrundlag, som er værd at udnytte $\mathrm{i}$ den videre udvikling af fysisk aktiverende rammer. Det er her væsentligt at fæste sig ved, at anlæg skal være dynamiske i sin egenskab, der på den ene side afspejler aktuelle adfærdsmønstre, men på den anden side også forsøger at bryde gænge forestillinger om, hvad bevægelse er. På den måde kan der indrettes bevægelsesfremmende anlæg, som både fastholder eksisterende brugergrupper og appellerer til, at nye grupper bydes op til aktivitet.

\section{REFERENCER}

Ajzen, I., \& Driver, B. L. (1992). Application of the Theory of Planned Behavior to Leisure Choice. Journal of Leisure Research, 24(3), $207-$ 224.

Bauman, A. E. (2004). Updating the evidence that physical activity is good for health: an epidemiological review 2000-2003. J Sci Med Sport, 7(1 Suppl), 6-19.

Blair, S. N. (2009). Physical inactivity: the biggest public health problem of the 21st century. Br J Sports Med, 43(1), 1-2.

Cavill, N., \& Bauman, A. (2004). Changing the way people think about health-enhancing physical activity: do mass media campaigns have a role? J Sports $S c i, 22(8), 771-790$.
Crawford, D. W., Jackson, E. L., \& Godbey, G. (1991). A Hierarchical Model of Leisure Constraints. Leisure Sciences, 13(4), 309-320.

Forebyggelseskommissionen. (2009). Vi kan leve langere og sundere: Forebyggelseskommissionens anbefalinger til en styrket forebyggende indsats. Kbh.: Forebyggelseskommissionen.

Franco, M., Orduñez, P., Caballero, B., Tapia Granados, J. A., Lazo, M., Bernal, J. L., . . . Cooper, R. S. (2007). Impact of energy intake, physical activity, and population-wide weight loss on cardiovascular disease and diabetes mortality in Cuba, 1980-2005. American Journal of Epidemiology, 166(12), 1374-1380.

Indenrigs-, \& Sundhedsministeriet. (2008). Kommunalreformen: Indenrigs- og Sundhedsministeriet.

Neuman, L.V. (2011). Social Research Methods: Quantitative and Qualitative Approaches, $7^{\text {th }}$ edition, Pearson Education.

Pawlowski, C.S \& Troelsen, J. (2012) En God Omvej - Bevægelse i lokalområdet. Kvalitativ analyse af den kommunale planlægnings- og implementeringsproces. [Odense]: Syddansk Universitet, Institut for Idræt og Biomekanik.

Pawlowski, C. S. (2012a). Byens arena: evaluering af en omdannet parkeringsplads ved boligbebyggelse i Høje Gladsaxe. [Odense]: Syddansk Universitet, Institut for Idræt og Biomekanik.

Pawlowski, C. S. (2012b). En voldsom omvej: evaluering af en omdannet støjvold $i$ Solrød. [Odense]: Syddansk Universitet, Institut for Idræt og Biomekanik. 
Pawlowski, C. S. (2012c). Et bevaegelseseksperimentarium: evaluering af en omdannet park ved sundhedscentret $i$ Nykøbing Sjalland. [Odense]: Syddansk Universitet, Institut for Idræt og Biomekanik.

Pawlowski, C. S. (2012d). Naturparken mellem Bakkedrag og Dalstrøg: evaluering af en omdannet grasmark ved boligbebyggelse i Sønderborg. [Odense]: Syddansk Universitet, Institut for Idræt og Biomekanik.

Pawlowski, C. S. (2012e). Opfordring til udfordring: evaluering af omdannede restarealer $i$ Kolding Bycentrum. [Odense]: Syddansk Universitet, Institut for Idræt og Biomekanik.

Pawlowski, C. S. (2012f). Pixlpark - en digital legeplads: evaluering af en omdannet plads $i$ en ny bydel i Roskilde. [Odense]: Syddansk Universitet, Institut for Idræt og Biomekanik.
Pawlowski, C. S. (2012g). Sidesporet-evaluering af en omdannet asfaltplads ved Nørre Aaby station. [Odense]: Syddansk Universitet, Institut for Idræt og Biomekanik.

Pawlowski, C. S., Christiansen, L. B., Schipperijn, J., \& Troelsen, J. (2013). En God Omvej - Bevagelse i lokalområdet. Samlet evaluering af otte kommunale anloegsprojekter til fremme af rekreativ fysisk aktivitet. Odense: Syddansk Univerrsitet, Institut for Idræt og Biomekanik.

Troelsen, J. (2013). Building in prevention: Nudging towards Physical Activity. In A. E. Christiane Stock (Ed.), Neighbourhood, Structure and Health Promotion (pp. 367). New York: Springer.

World Health Orginasation - WHO (2010). Global recommendations on physical activity for health, (pp. 58) Geneva, Switzerland.

\section{NOTER}

1 Anlægning af EGO projektet i Ringkøbing-Skjern Kommune blev forsinket og indgår derfor ikke i forskningsstudiet 